\title{
The interplay between the immune system and SARS-CoV-2 in COVID-19 patients
}

\author{
Sana Shabbir ${ }^{1} \cdot$ Muhammad Hassan $\operatorname{Raza}^{2} \cdot$ Muhammad Arshad $^{2} \cdot$ Muhammad Jawad Khan $^{1}(\mathbb{C}$
}

Received: 2 February 2021 / Accepted: 1 March 2021 / Published online: 5 May 2021

( $)$ The Author(s), under exclusive licence to Springer-Verlag GmbH Austria, part of Springer Nature 2021

\begin{abstract}
Millions of people across the globe have been affected by coronavirus disease 2019 (COVID-19), which began in Wuhan, China, and is caused by SARS-CoV-2. COVID-19 has a variety of clinical characteristics and triggers immune responses required for the elimination of the viral agent. Currently, no effective treatment options are available for targeting SARSCoV-2 infection. Repurposing of drugs such as chloroquine, thalidomide, and leflunomide alongside convalescent plasma is being employed as a therapeutic strategy. Clinical studies have shown that both asymptomatic and symptomatic patients can have an extremely active immune response that is largely attributable to immune system modulations. This includes cytokine storm syndrome (CSS), which affects the adaptive immune system, leading to exhaustion of natural killer (NK) cells and thrombocytopenia in some cases. This review examines the interaction of SARS-CoV-2 with the host immune system and the potential for the development of appropriate immunotherapy for the treatment of COVID-19.
\end{abstract}

\section{Introduction}

In December 2019, a distinct case of pneumonia characterized by typical clinical features of viral pneumonia was reported in Hubei province of the People's Republic of China. Analysis of respiratory samples revealed that a novel coronavirus was responsible for this pneumonia, which was later referred to as "novel coronavirus pneumonia" (NCP) [1]. The disease was officially named "coronavirus disease 2019" (COVID-19) by the World Health Organization (WHO). Coronaviruses are enveloped viruses with singlestranded RNA (ssRNA) and a helical nucleocapsid, and they are responsible for infections of the respiratory and intestinal tracts. SARS-CoV was responsible for an outbreak of severe

Handling Editor: Pablo Pineyro.

Muhammad Arshad

m.arshad@iiu.edu.pk

$\triangle$ Muhammad Jawad Khan jawadkhan@comsats.edu.pk

1 Department of Biosciences, COMSATS University Islamabad, Park Road, Chak Shahzad, Islamabad 45550, Pakistan

2 Department of Biological Sciences, International Islamic University Islamabad, Sri Nagar Highway, H10, Islamabad 45550, Pakistan acute respiratory syndrome (SARS) in China in 2002, and an outbreak of Middle East respiratory syndrome (MERS) was caused by MERS-CoV in the Middle East [2-5]. Earlier last year, another coronavirus outbreak was reported, and the novel coronavirus was named "SARS-CoV-2" because of its similarities to SARS-CoV [6, 7]. Currently, the molecular mechanism underlying the infectious activity of SARSCoV-2 is poorly understood, although structural analysis of the virus indicates that it may infect human cells by using angiotensin-converting enzyme 2 (ACE2) as a receptor [7]. The zoonotic spread of SARS-CoV-2 is not clear yet, but human-to-human transmission was reported at a marketplace where wild animals were sold, and studies have also indicated that the three above-mentioned viruses are likely to have originated from bats $[6,8,9]$.

SARS-CoV-2 is a member of the subfamily Coronavirinae, which includes four genera: Alphacoronavirus, Betacoronavirus, Gammacoronavirus, and Deltacoronavirus [10]. Some members of the first two of these genera infect humans. SARS-CoV-2, like SARS-CoV and MERS-CoV, is a member of the genus Betacoronavirus [11]. The SARS-CoV-2 genome is similar to that of SARS-like bat coronaviruses, and SARS$\mathrm{CoV}$, it relies on ACE2 as a receptor to infect human cells [12, 13]. The $\mathrm{S}$ (spike) protein present on the surface of the coronavirus is responsible for recognition of the receptor. Structural modeling of the binding of SARS-CoV-2 indicates that it is predicted to attach with more than tenfold higher affinity than 
SARS-CoV [14]. However, the underlying mechanism of the pathophysiology of SARS-CoV-2 is still unknown.

Clinical illness in patients infected with SARS-CoV-2 varies from a mild respiratory condition to severe acute respiratory illness and renal failure [1]. Pneumonia is the most prevalent clinical feature of SARS-CoV-2 infection, although the length of time until the appearance of clinical symptoms after infection varies from patient to patient; the average period is 14 days [15]. Health facilities are conducting diagnosis of COVID-19, and non-invasive diagnosis involves the detection of viral RNA. Real-time PCR (qPCR) is employed for the diagnosis of COVID-19 by detecting the presence of viral RNA in sputum, the throat, and the respiratory tract. This method is highly specific, but its relatively low sensitivity can lead to false-negative results [16]. The white blood cell (WBC) count varies among patients with COVID-19, and lymphopenia is frequently observed [17]. Increased levels of lactate dehydrogenase and ferritin have also been reported. Computed tomography (CT) of the chest region may be useful in diagnosis, yet it cannot rule out the presence of COVID-19 [18]. For qPCR, the type of sample and time of collection play a key role in the diagnosis. In the early phase of infection, the virus can be detected in respiratory samples, whereas serum samples give negative results, even though studies have suggested the presence of a high viral load in the early days of infection [19]. In addition to qPCR, testing methodologies including RT-loop-mediated isothermal amplification (RT-LAMP) and RT-insulated isothermal PCR (RT-iiPCR) have also been reported. Comparative analysis focused on results of serology-based testing (e.g., ELISA) and nucleic-acid-based molecular testing (e.g., PCR) has shown that PCR has better sensitivity and specificity. A CRISPR-based testing system was developed by Zhang et al. for the detection of SARS-CoV-2 within 60 minutes using the SHERLOCK methodology [20]. This technology might pave the way for developments in pointof-care (POC) testing for COVID-19. A rapid sequencing method has also been developed for SARS-CoV-2 that is based on rapid construction of the transcriptomics sequencing library [21].

Currently, no effective treatment is available for COVID19. The purpose of this article is to review the interactions between immune system and SARS-CoV-2 and the potential for the development of immunotherapy for the treatment of COVID-19 patients.

\section{Immune system interference by SARS-CoV-2}

\section{Cytokine storm syndrome}

SARS-CoV-2 infection leads to severe complications by targeting the adaptive immune system and causing lymphopenia [22] (Fig. 1, Table 1). It halts the production of antibodies and the $\mathrm{T}$ cell response, resulting in inflammation [23]. If inflammation is not controlled by the adaptive immune system within 7-10 days of infection, it distorts the adaptive immune response and results in "cytokine storm syndrome" (CSS). Previous studies have shown that CSS also occurs in patients with streptococcal toxic-shock-like syndrome (STSLS) caused by Streptococcus suis and in influenza patients [24, 25]. CSS is manifested by sustained fever, liver dysfunction, and coagulopathy. These are obvious clinical features of COVID-19 as well [26]. CSS results in the secretion of inflammation-specific cytokines; i.e., interleukin (IL)-1, IL-2, IL-8, IL-12, IL-18, tumor necrosis factor-alpha (TNF- $\alpha$ ), granulocyte-macrophage colonystimulating factor (GM-CSF), and interferon-gamma (IFN$\gamma$ ) [27]. IL- $1 \beta$ and IL- 8 induce the expression of IL- 6 and IL-17. The high IL-6 level has a suppressive effect on the immune system (Fig. 1a). By inhibiting the production of IFN- $\gamma$, it has a negative effect on the production of $\mathrm{CD} 8^{+}$ cytotoxic T cells [28]. As a result, COVID-19 patients are unable to produce an adaptive immune response (antigenspecific B cells and antibodies) [27]. An increased level of IL-6 leads to its movement towards the liver via the bloodstream, where it causes the induction of serum amyloid A (SAA) [29]. SAA accumulation results in chronic inflammatory diseases by producing amyloid A amyloidosis. Amyloid fibril deposits in various organs can result in their dysfunction [30]. IL-6 in bone marrow promotes megakaryocyte maturation, resulting in an elevated platelet count, thus causing blood clots. Many patients with severe COVID-19 experience clotting. This might be due to disruption of the immune system by the infection. High platelet counts are a sign of inflammation and can thus act as a biomarker of immune system dysregulation [26].

\section{Exhaustion of NK and $\mathrm{CD}^{+} \mathrm{T}$ cells}

Natural killer (NK) cells are components of the innate immune system and exhibit lymphocytic activity against tumors and microbial infections (Table 1). Various studies have highlighted their reciprocal relationship with neighboring macrophages, endothelial cells, and T cells [37]. The antagonistic activity between NK cells and their neighboring cells helps to regulate NK cell activation and determine whether NK cells are able to perform their killing function [38]. A recent study performed in China showed that COVID-19 patients who were struggling with severe disease symptoms (SDS) had lower NK cell counts than patients with mild disease symptoms (MDS). These patients showed elevated expression of NKG2A receptors, which are inhibitory receptors present on the NK cell surface that gradually diminish its function, leading to disease progression (Fig. 1b). It has been suggested that the downregulation of 


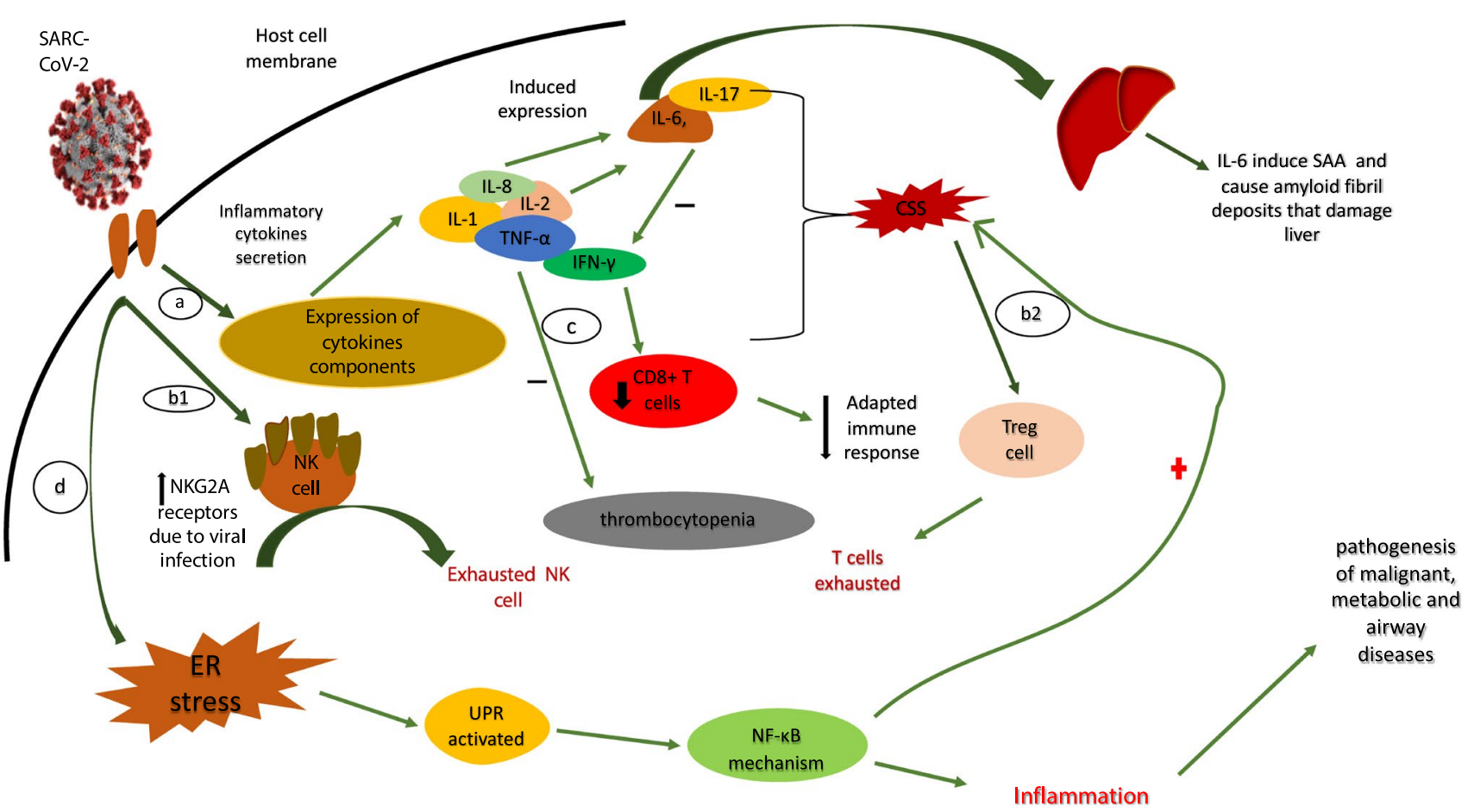

Fig. 1 Pathway illustrating four different ways by which SARSCoV-2 interferes with the immune system. (a) SARS-CoV-2 infection results in cytokines stress syndrome by producing a cascade of inflammatory cytokines such as interleukin 1 (IL-1), IL-2, IL-8, TNF- $\alpha$, tumor necrosis factor-alpha, and interferon-gamma (IFN- $\gamma$ ) through the activation of cytokine components. IL-2 and IL-8 further induce the expression of IL-6 and IL-17. CSS is characterized by a high level of IL-6. IL-6 causes liver damage by producing SAA serum amyloid. (b) SARS-CoV-2 infection causes the upregulation of
NK cell receptors (NKG2A). High NKG2A levels halt the function of NK cells by exhausting them (b1). Simultaneously, T cell exhaustion occurs due to the activation of Treg cells because of CSS (b2). (c) Increased expression of TNF- $\alpha$ due to CSS causes thrombocytopenia. (d) SARS-CoV-2 infection causes ER endoplasmic reticulum stress, which activates the unfolded protein response (UPR). Prolonged stress results in activation of the NF- $\mathrm{BB}$ pathway, which causes inflammation and ultimately leads to the pathogenesis of malignant, metabolic, and airway diseases.

Table 1 Characteristics and clinical features of patients with immune system complications caused by SARS-CoV-2 infection

\begin{tabular}{|c|c|c|c|}
\hline $\begin{array}{l}\text { Immune-system-related compli- } \\
\text { cations of COVID-19 }\end{array}$ & Characteristics & Clinical features & References \\
\hline Cytokine storm & High level of inflammatory cytokines & $\begin{array}{l}\text { IL-6: vascular leakage, coagulation } \\
\text { TNF- } \alpha \text { : flu-like symptoms } \\
\text { IFN- } \gamma \text { : fatigue, malaise }\end{array}$ & {$[31]$} \\
\hline NK cell exhaustion & NK cell function lost & chronic infection & {$[32]$} \\
\hline $\mathrm{T}$ cell exhaustion & $\mathrm{CD}^{+} \mathrm{T}$ cell dysfunction & $\begin{array}{l}\text { Loss of effector (by producing perforins and } \\
\text { granzymes), metabolic, memory and self- } \\
\text { renewal function }\end{array}$ & [33] \\
\hline Thrombocytopenia & Extreme reduction in platelet count & $\begin{array}{l}\text { Liver damage (thrombosis), } \\
\text { hemorrhagic complications }\end{array}$ & {$[34]$} \\
\hline ER-stress-mediated inflammation & $\begin{array}{l}\text { Activation of tumor-promoting cytokines } \\
\text { ER stress caused by excessive viral protein } \\
\text { production and modification for viral replica- } \\
\text { tion and infection }\end{array}$ & $\begin{array}{l}\text { Inflammatory microenvironment, } \\
\text { cancer aggressiveness, } \\
\text { pathogenesis of metabolic and airway diseases }\end{array}$ & {$[35,36]$} \\
\hline
\end{tabular}

the NKG2A receptor might play a role in controlling the disease [7].

$\mathrm{T}$ lymphocytes are categorized as $\mathrm{CD}^{+}$cytotoxic lymphocytes (CTLs), CD4 helper (Th) cells, and regulatory (Treg) $\mathrm{T}$ cells [33]. $\mathrm{CD}^{+}$cells eliminate the virus by producing a cascade of pathogen-killing molecules such as IFN- $\gamma$, granzymes, and perforins, while $\mathrm{CD}^{+}{ }^{+}$cells assist $\mathrm{CD}^{+}$cells in clearing viral infection more effectively [39]. Treg cells suppress the activation of both $\mathrm{CD}^{+}$and helper cells and maintain the cell count balance. A study 
performed on 499 COVID-19 patients with MDS showed reduced $\mathrm{CD} 8^{+}$and $\mathrm{CD} 4^{+}$cell counts $(70.56 \%$ of total MDS patients). About $90.5 \%$ of critical-stage patients showed an extreme reduction in their total $\mathrm{T}$ cell count, especially $\mathrm{CD}^{+}$cells [40]. Another study on COVID-19 patients also showed a reduction in $\mathrm{T}$ cell counts and Treg cell upregulation due to a cytokine storm [33]. Treg cell activation with its surface marker forkhead box P3 (FoxP3) reduces $\mathrm{T}$ cell activation, and therefore, patients with COVID-19 cannot maintain long-term activation of $\mathrm{T}$ cells and enter a phase of "exhaustion". Exhausted T cells (Tex) express programmed death-1 (PD-1) and T cell immunoglobulin \& mucindomain-3 (Tim-3); (CD366) markers and thus lose their effector, metabolic, memory, and self-renewal function. Targeting NKG2A receptors and Treg cell upregulation by IL-6 and IL-10 may help in preventing T cell exhaustion.

\section{Thrombocytopenia}

Thrombocytopenia occurs when the platelet count is less than $150,000 / \mu 1$ [41]. A decrease in platelet count is an alarming sign of severe complications of the innate immune system and in most cases results in death [42]. Thrombocytopenia is characterized by multiple organ dysfunction [43] caused by megakaryocytes present in the lungs. Morphological changes in the lung capillary bed due to mechanical ventilation or viral infection result in deranged thrombocyte defragmentation (Fig. 1c) [44]. Findings from one study indicated that IL-3, IL-6, IL-11, and dysregulated thrombopoietin (TPO) influence the production of megakaryocytes from hematopoietic cells [45]. Megakaryocyte inhibition occurs through the action of inhibitory cytokines such as interferon- $\alpha$ and transforming growth factor (TGF)- $\beta$ [13]. Thrombocytopenia leads to hemorrhagic complications [42]. A meta-analysis of 1725 COVID-19 patients, 245 of which were critical patients, found a $57.7 \%$ reduction in platelet counts from the normal range in patients with SDS. This suggests that viral infection results in endothelial damage, which activates platelet production and aggregation, leading to lung thrombosis [34]. Therefore, in addition to cytokine storm and $\mathrm{T}$ cell exhaustion, thrombocytopenia can be another separate biomarker for COVID-19 infection.

\section{ER-stress-mediated inflammation}

The endoplasmic reticulum (ER) is a site where various essential protein modifications occur [46]. When the capacity of the ER to synthesize and modify proteins reaches a certain limit, it becomes overburdened and enters a stress phase. ER stress activates the unfolded protein response (UPR), which restores normal ER functioning by producing proinflammatory molecules (Fig. 1d) [47]. SARS-CoV stresses the ER in three ways: by forming double-membrane vesicles (DMV), by glycosylating its structural proteins, and by depleting the ER membrane of lipids by using them for budding and release of virions [48, 49]. Knoops et al. described the structure of SARS-CoV-affected ER using high-resolution electron tomography [50]. The study suggested that SARS-CoV utilizes the ER membrane for formation of DMVs. The SARS-CoV M protein (transmembrane protein) is glycosylated, and the glycosylation can be either $\mathrm{O}$-linked or N-linked. The M protein, if not glycosylated, can induce production of interferon alpha (IFN- $\alpha$ ) [51]. The three above-mentioned ER-stress-producing processes are required for SARS-CoV replication. Prolonged ER stress causes the UPR signaling pathway to trigger inflammation by the NF- $\mathrm{KB}$ pathway, leading to excessive cytokine production (Fig. 1d) [52]. UPR-mediated inflammation governs the pathogenesis of malignant, metabolic, and airway diseases [35]. SARS-CoV infection imposes stress on the ER and aggravates cancer pathogenesis in the inflammatory microenvironment. Inflammation leads to CSS, which activates tumor-promoting cytokines. Recent studies on the association of cancer aggressiveness with COVID-19 have shown that patients with an active tumor or undergoing anticancer treatment are at greater risk of death after infection with SARS-CoV-2 [36]. The specific reason for the high mortality rate in cancer patients is not yet known, but different hypothesis-based studies and reviews emphasize that ER stress could be one of the leading causes.

\section{Immunotherapy and COVID-19}

Currently, no effective and specific treatment targeting SARS-CoV-2 is available. Therapeutic strategies employed in the clinics include supportive medication (Fig. 2) [53], the majority of which do not improve the quality of life of patients. For instance, a combination of interferons along with ribavirin has shown limited efficacy against COVID19. Glucocorticoids have also been found to be ineffective in numerous cases. Currently, clinical trials focused on the use of corticosteroids for the treatment of COVID-19 are being conducted [54], although limited data are available about their use in earlier pandemics caused by coronaviruses [55, 56]. Tocilizumab, an antagonist of interleukin-6, together with sarilumab, is being tested in clinical trials for the treatment of COVID-19 [57, 58]. Alternatively, CytoSorb, an adjunctive therapeutic molecule that absorbs a variety of cytokines, leading to a reduction in their concentration, has been shown to improve the immunopathological condition of patients [54]. A COVID-19 patient has been successfully treated with the immunomodulator thalidomide [57]. A combination of azithromycin and the antimalarial drug hydroxychloroquine has shown potential for the treatment of COVID-19 in a small non-randomized clinical trial [59]. However, limited data are available on the modulation of 


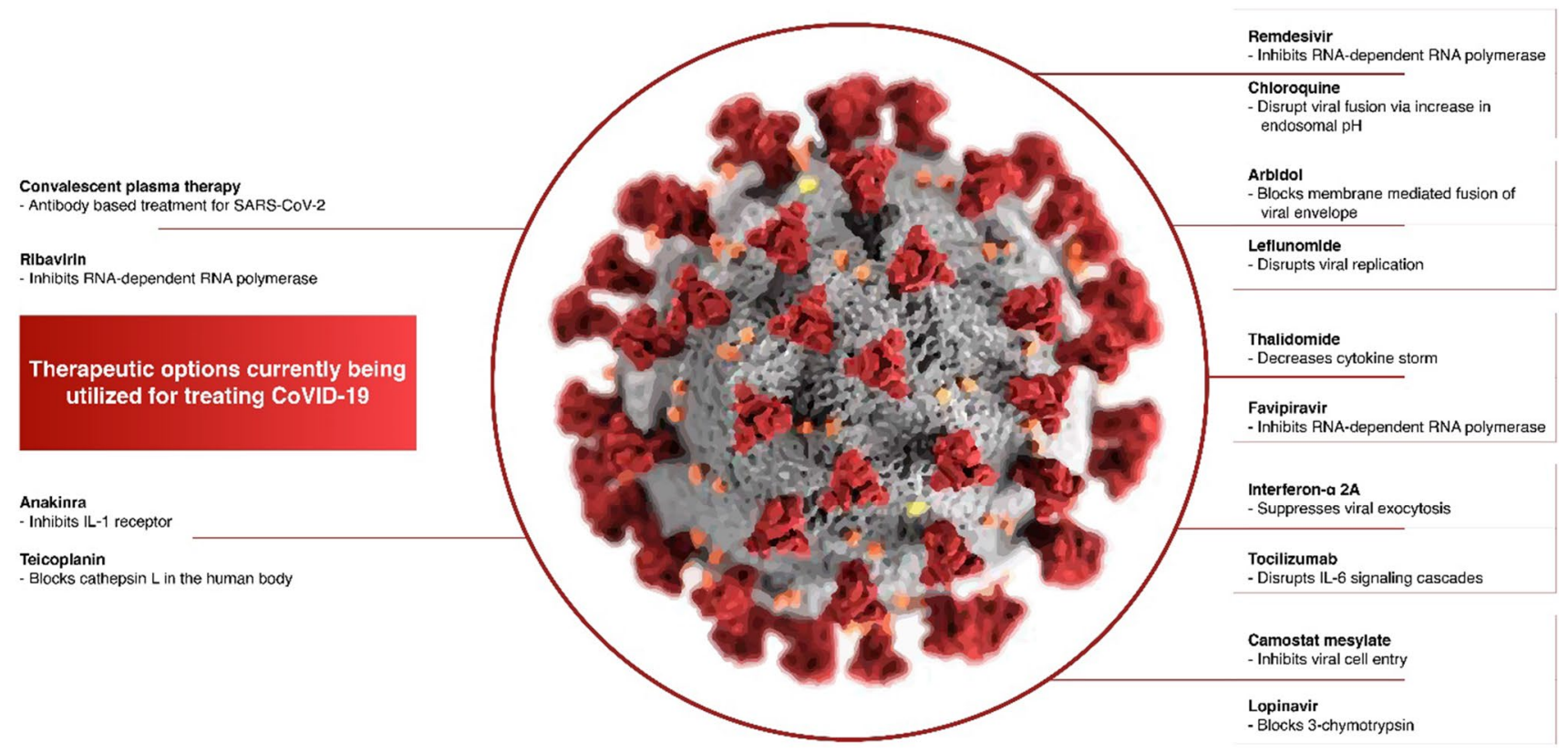

Fig. 2 Currently employed therapeutic strategies for treatment of COVID-19

the immune system via hydroxychloroquine for targeting COVID-19 [60].

SARS-CoV-2 modulates levels of both T cells and B cells, and this characteristic can be exploited to develop therapeutic strategies targeting the infectious agent. Clinical evaluation of vaccines against SARS-CoV in experimental animal models has indicated the presence of immunopathological modulation linked with Th2-cell-controlled eosinophil penetration $[61,62]$. An experiment using a mouse model showed increased immunopathology instead of protection [63]. The development of vaccines based on their interaction with $\mathrm{T}$ cells requires a comparative evaluation of the molecular mechanisms underlying protective $\mathrm{T}$ cell activation and harmful $\mathrm{T}$ cell production [64].

A B cell response was observed in COVID-19 patients approximately 1 week after the onset of symptoms, and the nucleocapsid $(\mathrm{N})$ protein is the first target of T cells [65], with the production of antibodies against $\mathrm{S}$ protein immediately after the onset of symptoms [66]. Antibody production can also be detected earlier in COVID-19 patients, but many patients do not develop persistent antibodies, and the possibility of reinfection in such patients remains unknown. The administration of antibodies appears to be an effective treatment for COVID-19 patients, as has been shown in cases of infection with both SARS-CoV-2 and SARS-CoV [67-71]. The molecular mechanism of protection against the virus has not been elucidated in humans. In SARS-CoV infection, neutralizing antibodies target the
S protein, which binds to the ACE2 receptor on human cells [72]. Monoclonal antibodies targeting SARS-CoV can also bind to SARS-CoV-2 but with less affinity due to differences in target regions of the antibodies [73, 74]. Furthermore, cross-neutralization of SARS-CoV-2 by a mouse anti-SARS-CoV antiserum has been described [75].

Convalescent plasma has been used as a source of polyclonal antibodies against SARS-CoV-2 for the treatment of COVID19 patients [76]. Therapeutic strategies for developing monoclonal antibodies to neutralize SARS-CoV-2 have included phage library display and immunization of experimental mice [77, 78]. The absence of antibodyescape mechanisms, i. e., glycan coating of the receptorattachment site suggests that if SARS-CoV-2 behaves in a manner similar to SARS-CoV, development of monoclonal antibodies for the treatment of infection will be successful $[54,79]$. Currently, effective commercial monoclonal antibodies for the treatment of SARS-CoV-2 infection are not available, despite significant advancements in the development of therapeutic monoclonal antibodies for the treatment of COVID-19 using passive immunization approaches. Although the commercial-scale production of monoclonal antibodies for targeting SARS-CoV-2 is not cost- and time-efficient, designing an optimized and tailored antibody production platform can play a vital role in this regard. Further studies on structural and immunopathological data on coronaviruses can help in the treatment of SARS-CoV-2 using immunotherapy approaches. 


\section{Conclusion}

COVID-19 has caused massive destruction worldwide, and nations are still striving to get back to normal. Scientists and physicians are working hard to find effective treatments, although robust diagnosis is still a concern because of ambiguity in the detection of viral infection. This review was an effort to highlight important possible ways by which SARS$\mathrm{CoV}-2$ interferes with the immune system and immunebased drugs used in different countries. CSS, thrombocytopenia, and $\mathrm{T}$ cell exhaustion provide insight into how COVID-19 interferes with the immune system, and these aspects can also help in the discovery of biomarkers for diagnosis of COVID-19. Recent studies have reported CSS to be a major factor in this disease, so targeting different aspects of CSS might help in designing drugs that mainly focus on the immune system. Many immune-system-based drugs have already been designed and a few of them are in clinical trials. These drugs have shown promising results, and immunotherapy could thus prove to be the most important future treatment of COVID-19. Thrombocytopenia is a very reliable indicator of viral infection. Also, we can look forward to integrating ER stress as a biomarker with assaybased techniques to measure ER stress and its role in disease pathogenesis.

Acknowledgement The authors acknowledge the hard work of all the scientists working on vaccine development and treatment of COVID19 and health emergency workers, fighting against the virus during the COVID-19 pandemic.

Author contributions All authors have equal contribution in data collection and writing. Sana Shabbir and Muhammad Hassan Raza proposed the idea for the article. Both of them performed literature search, and Sana Shabbir wrote the first draft. Muhammad Arshad and Muhammad Jawad Khan supervised and critically revised the work.

Funding Not applicable

\section{Declarations}

Conflict of interest The authors declare that they have no conflict of interest.

Ethical approval This article does not contain any studies with human participants or animals performed by any of the authors.

\section{References}

1. Huang C, Wang Y, Li X, Ren L, Zhao J, Hu Y, Zhang L, Fan G, Xu J, Gu X, Cheng Z, Yu T, Xia J, Wei Y, Wu W, Xie X, Yin W, Li H, Liu M, Xiao Y, Gao H, Guo L, Xie J, Wang G, Jiang R, Gao Z, Jin Q, Wang J, Cao B (2020) Clinical features of patients infected with 2019 novel coronavirus in Wuhan, China. Lancet 395(10223):497-506. https://doi.org/10.1016/S0140-6736(20) 30183-5
2. Zhong NS, Zheng BJ, Li YM, Poon XZH, Chan KH, Li PH, Tan SY, Chang Q, Xie JP, Liu XQ, Xu J, Li DX, Yuen KY, Peiris GY (2003) Epidemiology and cause of severe acute respiratory syndrome (SARS) in Guangdong, People's Republic of China, in February. Lancet 362(9393):1353-1358. https://doi.org/10.1016/ s0140-6736(03)14630-2

3. Zaki AM, van Boheemen S, Bestebroer TM, Osterhaus AD, Fouchier RA (2012) Isolation of a novel coronavirus from a man with pneumonia in Saudi Arabia. N Engl J Med 367(19):18141820. https://doi.org/10.1056/NEJMoa1211721

4. Cui J, Li F, Shi ZL (2019) Origin and evolution of pathogenic coronaviruses. Nat Rev Microbiol 17(3):181-192. https://doi.org/ 10.1038/s41579-018-0118-9

5. Bawazir A, Al-Mazroo E, Jradi H, Ahmed A, Badri M (2018) MERS-CoV infection: mind the public knowledge gap. J Infect Public Health 11(1):89-93. https://doi.org/10.1016/j.jiph.2017. 05.003

6. Chen Y, Liu Q, Guo D (2020) Emerging coronaviruses: Genome structure, replication, and pathogenesis. J Med Virol 92(4):418 423. https://doi.org/10.1002/jmv.25681

7. Zhou P, Yang XL, Wang XG, Hu B, Zhang L, Zhang W, Si HR, Zhu Y, Li B, Huang CL, Chen HD, Chen J, Luo Y, Guo H, Jiang RD, Liu MQ, Chen Y, Shen XR, Wang X, Zheng XS, Zhao K, Chen QJ, Deng F, Liu LL, Yan B, Zhan FX, Wang YY, Xiao GF, Shi ZL (2020) A pneumonia outbreak associated with a new coronavirus of probable bat origin. Nature 579(7798):270-273. https://doi.org/10.1038/s41586-020-2012-7

8. Ithete NL, Stoffberg S, Corman VM, Cottontail VM, Richards LR, Schoeman MC, Drosten C, Drexler JF, Preiser W (2013) Close relative of human Middle East respiratory syndrome coronavirus in bat, South Africa. Emerg Infect Dis 19(10):1697-1699. https:// doi.org/10.3201/eid1910.130946

9. Raj VS, Mou H, Smits SL, Dekkers DH, Müller MA, Dijkman R, Muth D, Demmers JA, Zaki A, Fouchier RA, Thiel V, Drosten C, Rottier PJ, Osterhaus AD, Bosch BJ, Haagmans BL (2013) Dipeptidyl peptidase 4 is a functional receptor for the emerging human coronavirus-EMC. Nature 495(7440):251-254. https://doi. org/10.1038/nature 12005

10. Chan JF, To KK, Tse H, Jin DY, Yuen KY (2013) Interspecies transmission and emergence of novel viruses: lessons from bats and birds. Trends Microbiol 21(10):544-555. https://doi.org/10. 1016/j.tim.2013.05.005

11. Zhu N, Zhang D, Wang W, Li X, Yang B, Song J, Zhao X, Huang B, Shi W, Lu R, Niu P, Zhan F, Ma X, Wang D, Xu W, Wu G, Gao GF, Tan W (2020) China Novel Coronavirus Investigating and Research Team. A novel coronavirus from patients with pneumonia in China, 2019. N Engl J Med 382(8):727-733. https://doi.org/ 10.1056/NEJMoa2001017

12. Wu A, Peng Y, Huang B, Ding X, Wang X, Niu P, Meng J, Zhu Z, Zhang Z, Wang J, Sheng J, Quan L, Xia Z, Tan W, Cheng G, Jiang T (2020) Genome composition and divergence of the novel coronavirus (2019-nCoV) originating in China. Cell Host Microbe 27(3):325-328. https://doi.org/10.1016/j.chom.2020.02.001

13. Hofmann WK, Kalina U, Koschmieder S, Seipelt G, Hoelzer D, Ottmann OG (2000) Defective megakaryocytic development in myelodysplastic syndromes. Leuk Lymphoma 38(1-2):13-19. https://doi.org/10.3109/10428190009060315

14. Wrapp D, Wang N, Corbett KS, Goldsmith JA, Hsieh CL, Abiona O, Graham BS, McLellan JS (2020) Cryo-EM structure of the 2019-nCoV spike in the prefusion conformation. Science 367(6483):1260-1263. https://doi.org/10.1126/science.abb2507

15. Khan S, Siddique R, Shereen MA, Ali A, Liu J, Bai Q, Bashir N, Xue M (2020) Emergence of a novel coronavirus, severe acute respiratory syndrome coronavirus 2: biology and therapeutic options. J Clin Microbiol 58(5):e00187-e220. https://doi.org/10. 1128/JCM.00187-20 
16. Wang L, Wang Y, Ye D, Liu Q (2020) Review of the 2019 novel coronavirus (SARS-CoV-2) based on current evidence. Int J Antimicrob Agents 55(6):105948. https://doi.org/10.1016/j.ijant imicag.2020.105948

17. Lippi G, Simundic AM, Plebani M (2020) Potential preanalytical and analytical vulnerabilities in the laboratory diagnosis of coronavirus disease 2019 (COVID-19). Clin Chem Lab Med 58(7):1070-1076. https://doi.org/10.1515/cclm-2020-0285

18. Li Y, Xia L (2020) Coronavirus disease 2019 (COVID-19): role of chest $\mathrm{CT}$ in diagnosis and management. AJR Am J Roentgenol 214(6):1280-1286. https://doi.org/10.2214/AJR.20.22954

19. Pang J, Wang MX, Ang IYH, Tan SHX, Lewis RF, Chen JI, Gutierrez RA, Gwee SXW, Chua PEY, Yang Q, Ng XY, Yap RK, Tan HY, Teo YY, Tan CC, Cook AR, Yap JC, Hsu LY (2020) Potential rapid diagnostics, vaccine and therapeutics for 2019 novel coronavirus (2019-nCoV): a systematic review. J Clin Med 9(3):623. https://doi.org/10.3390/jcm 9030623

20. Zhang F, Abudayyeh OO, Gootenberg JS (2020) A protocol for detection of COVID-19 using CRISPR diagnostics. Broad Institute MIT, Cambridge

21. Di L, Fu Y, Sun Y, Li J, Liu L, Yao J, Wang G, Wu Y, Lao K, Lee RW, Zheng G, Xu J, Oh J, Wang D, Xie XS, Huang Y, Wang J (2020) RNA sequencing by direct tagmentation of RNA/DNA hybrids. Proc Natl Acad Sci USA 117(6):2886-2893. https://doi. org/10.1073/pnas.1919800117

22. Stebbing J, Phelan A, Griffin I, Tucker C, Oechsle O, Smith D, Richardson P (2020) COVID-19: combining antiviral and antiinflammatory treatments. Lancet Infect Dis 20:400-402

23. Chousterman BG, Swirski FK, Weber GF (2017) Cytokine storm and sepsis disease pathogenesis. In: Seminars in immunopathology, vol 5. Springer, pp 517-528

24. Ferrara JL, Abhyankar S, Gilliland DG (1993) Cytokine storm of graft-versus-host disease: a critical effector role for interleukin-1. Transplant Proc 25(1 Pt 2):1216-1217

25. Lin L, Xu L, Lv W, Han L, Xiang Y, Fu L, Jin M, Zhou R, Chen H, Zhang A (2019) An NLRP3 inflammasome-triggered cytokine storm contributes to Streptococcal toxic shock-like syndrome (STSLS). PLoS Pathog 15(6):e1007795. https://doi.org/10.1371/ journal.ppat.1007795

26. Cascella M, Rajnik M, Cuomo A, Dulebohn SC, Di Napoli R (2020) Features, evaluation and treatment coronavirus (COVID19). In: Statpearls. StatPearls Publishing

27. Zhou Y, He C, Wang L, Ge B (2017) Post-translational regulation of antiviral innate signaling. Eur J Immunol 47:1414-1426

28. Velazquez-Salinas L, Verdugo-Rodriguez A, Rodriguez LL, Borca MV (2019) The role of interleukin 6 during viral infections. Front Microbiol 10:1057. https://doi.org/10.3389/fmicb.2019.01057

29. Tanaka T, Narazaki M, Kishimoto T (2014) IL-6 in inflammation, immunity, and disease. Cold Spring Harb Perspect Biol 6(10):a016295. https://doi.org/10.1101/cshperspect.a016295

30. Gillmore JD, Lovat LB, Persey MR, Pepys MB, Hawkins PN (2001) Amyloid load and clinical outcome in AA amyloidosis in relation to circulating concentration of serum amyloid A protein. Lancet 358:24-29

31. Sun X, Wang T, Cai D, Hu Z, Chen J, Liao H, Zhi L, Wei H, Zhang Z, Qiu Y, Wang J, Wang A (2020) Cytokine storm intervention in the early stages of COVID-19 pneumonia. Cytokine Growth Factor Rev 53:38-42. https://doi.org/10.1016/j.cytogfr. 2020.04.002

32. Zheng M, Gao Y, Wang G, Song G, Liu S, Sun D, Xu Y, Tian Z (2020) Functional exhaustion of antiviral lymphocytes in COVID19 patients. Cell Mol Immunol 17(5):533-535. https://doi.org/10. 1038/s41423-020-0402-2

33. Chiappelli F, Khakshooy A, Greenberg G (2020) CoViD19 Immunopathology and Immunotherapy. Bioinformation 16(3):219-222. https://doi.org/10.6026/97320630016219
34. Lippi G, Plebani M, Henry BM (2020) Thrombocytopenia is associated with severe coronavirus disease 2019 (COVID-19) infections: a meta-analysis. Clin Chim Acta 506:145-148. https://doi. org/10.1016/j.cca.2020.03.022

35. Garg AD, Kaczmarek A, Krysko O, Vandenabeele P, Krysko DV, Agostinis P (2012) ER stress-induced inflammation: does it aid or impede disease progression? Trends Mol Med 18(10):589-598. https://doi.org/10.1016/j.molmed.2012.06.010

36. Kuderer NM, Choueiri TK, Shah DP, Shyr Y, Rubinstein SM, Rivera DR, Shete S, Hsu CY, Desai A, de Lima Lopes G Jr, Grivas P, Painter CA, Peters S, Thompson MA, Bakouny Z, Batist G, Bekaii-Saab T, Bilen MA, Bouganim N, Larroya MB, Castellano D, Del Prete SA, Doroshow DB, Egan PC, Elkrief A, Farmakiotis D, Flora D, Galsky MD, Glover MJ, Griffiths EA, Gulati AP, Gupta S, Hafez N, Halfdanarson TR, Hawley JE, Hsu E, Kasi A, Khaki AR, Lemmon CA, Lewis C, Logan B, Masters T, McKay RR, Mesa RA, Morgans AK, Mulcahy MF, Panagiotou OA, Peddi P, Pennell NA, Reynolds K, Rosen LR, Rosovsky R, Salazar M, Schmidt A, Shah SA, Shaya JA, Steinharter J, Stockerl-Goldstein KE, Subbiah S, Vinh DC, Wehbe FH, Weissmann LB, Wu JT, Wulff-Burchfield E, Xie Z, Yeh A, Yu PP, Zhou AY, Zubiri L, Mishra S, Lyman GH, Rini BI, Warner JL (2020) COVID-19 and Cancer Consortium. Clinical impact of COVID-19 on patients with cancer (CCC19): a cohort study. Lancet 395(10241):19071918. https://doi.org/10.1016/S0140-6736(20)31187-9

37. Vivier E, Tomasello E, Baratin M, Walzer T, Ugolini S (2008) Functions of natural killer cells. Nat Immunol 9(5):503-510. https://doi.org/10.1038/ni1582

38. Vivier E, Nunès JA, Vély F (2004) Natural killer cell signaling pathways. Science 306(5701):1517-1519. https://doi.org/10.1126/ science. 1103478

39. Mescher MF, Curtsinger JM, Agarwal P, Casey KA, Gerner M, Hammerbeck CD, Popescu F, Xiao Z (2006) Signals required for programming effector and memory development by $\mathrm{CD} 8+\mathrm{T}$ cells. Immunol Rev 211:81-92. https://doi.org/10.1111/j.0105-2896. 2006.00382.x

40. Diao B, Wang C, Tan Y, Chen X, Liu Y, Ning L, Chen L, Li M, Liu Y, Wang G, Yuan Z, Feng Z, Zhang Y, Wu Y, Chen Y (2020) Reduction and functional exhaustion of $T$ cells in patients with coronavirus disease 2019 (COVID-19). Front Immunol 11:827. https://doi.org/10.3389/fimmu.2020.00827

41. Elgohary T, Zaghla HE, Azab A, Hagag T (2011) Role of thrombocytopenia as an independent prognostic marker in the critically Ill patients with multiorgan failure. Med J Cairo Univ 79:1-9

42. Khurana D, Deoke SA (2017) Thrombocytopenia in critically Ill patients: clinical and laboratorial behavior and its correlation with short-term outcome during hospitalization. Indian J Crit Care Med 21(12):861-864. https://doi.org/10.4103/ijccm.IJCCM_279_17

43. Vanderschueren S, De Weerdt A, Malbrain M, Vankersschaever D, Frans E, Wilmer A, Bobbaers H (2000) Thrombocytopenia and prognosis in intensive care. Crit Care Med 28(6):1871-1876. https://doi.org/10.1097/00003246-200006000-00031

44. Yang M, Ng MH, Li CK (2005) Thrombocytopenia in patients with severe acute respiratory syndrome (review). Hematology 10(2):101-105. https://doi.org/10.1080/10245330400026170

45. Will B, Zhou L, Vogler TO, Ben-Neriah S, Schinke C, Tamari R, Yu Y, Bhagat TD, Bhattacharyya S, Barreyro L, Heuck C, Mo Y, Parekh S, McMahon C, Pellagatti A, Boultwood J, Montagna C, Silverman L, Maciejewski J, Greally JM, Ye BH, List AF, Steidl C, Steidl U, Verma A (2012) Stem and progenitor cells in myelodysplastic syndromes show aberrant stage-specific expansion and harbor genetic and epigenetic alterations. Blood 120(10):20762086. https://doi.org/10.1182/blood-2011-12-399683

46. Kharroubi I, Ladrière L, Cardozo AK, Dogusan Z, Cnop M, Eizirik DL (2004) Free fatty acids and cytokines induce pancreatic beta-cell apoptosis by different mechanisms: role of nuclear 
factor-kappaB and endoplasmic reticulum stress. Endocrinology 145(11):5087-5096. https://doi.org/10.1210/en.2004-0478

47. Li Y, Schwabe RF, DeVries-Seimon T, Yao PM, Gerbod-Giannone MC, Tall AR, Davis RJ, Flavell R, Brenner DA, Tabas I (2005) Free cholesterol-loaded macrophages are an abundant source of tumor necrosis factor-alpha and interleukin-6: model of NF-kappaB- and map kinase-dependent inflammation in advanced atherosclerosis. J Biol Chem 280(23):21763-21772. https://doi. org/10.1074/jbc.M501759200

48. Fung TS, Liu DX (2014) Coronavirus infection, ER stress, apoptosis and innate immunity. Front Microbiol 5:296. https://doi.org/ 10.3389/fmicb.2014.00296

49. Shabbir S, Hafeez A, Rafiq MA, Khan MJ (2020) Estrogen shields women from COVID-19 complications by reducing ER stress. Med Hypotheses 143:110148. https://doi.org/10.1016/j.mehy. 2020.110148

50. Knoops K, Kikkert M, Worm SH, Zevenhoven-Dobbe JC, van der Meer Y, Koster AJ, Mommaas AM, Snijder EJ (2008) SARScoronavirus replication is supported by a reticulovesicular network of modified endoplasmic reticulum. PLoS Biol 6(9):e226. https:// doi.org/10.1371/journal.pbio.0060226

51. de Haan CA, de Wit M, Kuo L, Montalto-Morrison C, Haagmans BL, Weiss SR, Masters PS, Rottier PJ (2003) The glycosylation status of the murine hepatitis coronavirus $\mathrm{M}$ protein affects the interferogenic capacity of the virus in vitro and its ability to replicate in the liver but not the brain. Virology 312(2):395-406. https://doi.org/10.1016/s0042-6822(03)00235-6

52. Rius J, Guma M, Schachtrup C, Akassoglou K, Zinkernagel AS, Nizet V, Johnson RS, Haddad GG, Karin M (2008) NF-kappaB links innate immunity to the hypoxic response through transcriptional regulation of HIF-1alpha. Nature 453(7196):807-811. https://doi.org/10.1038/nature06905

53. Cinatl J, Morgenstern B, Bauer G, Chandra P, Rabenau H, Doerr HW (2003) Treatment of SARS with human interferons. Lancet 362(9380):293-294. https://doi.org/10.1016/s0140-6736(03) 13973-6

54. Tay MZ, Poh CM, Rénia L, MacAry PA, Ng LFP (2020) The trinity of COVID-19: immunity, inflammation and intervention. Nat Rev Immunol 20(6):363-374. https://doi.org/10.1038/ s41577-020-0311-8

55. Stockman LJ, Bellamy R, Garner P (2006) SARS: systematic review of treatment effects. PLoS Med 3(9):e343. https://doi.org/ 10.1371/journal.pmed.0030343

56. Tai DY (2007) Pharmacologic treatment of SARS: current knowledge and recommendations. Ann Acad Med Singap 36(6):438-443

57. Chen C, Qi F, Shi K, Li Y, Li J, Chen Y, Pan J, Zhou T, Lin X, Zhang J, Luo Y, Li X, Xia J (2020) Thalidomide combined with low-dose short-term glucocorticoid in the treatment of critical Coronavirus Disease 2019. Clin Transl Med 10(2):e35. https:// doi.org/10.1002/ctm2.35

58. Qiu R, Wei X, Zhao M, Zhong C, Zhao C, Hu J, Li M, Huang Y, Han S, He T et al (2020) Outcome reporting from protocols of clinical trials of Coronavirus Disease 2019 (COVID-19): a review. medRxiv. https://doi.org/10.1101/2020.03.04.20031401

59. Gautret P, Lagier JC, Parola P, Hoang VT, Meddeb L, Mailhe M, Doudier B, Courjon J, Giordanengo V, Vieira VE, Tissot Dupont $\mathrm{H}$, Honoré $\mathrm{S}$, Colson $\mathrm{P}$, Chabrière $\mathrm{E}$, La Scola $\mathrm{B}$, Rolain JM, Brouqui P, Raoult D (2020) Hydroxychloroquine and azithromycin as a treatment of COVID-19: results of an open-label nonrandomized clinical trial. Int J Antimicrob Agents 56(1):105949. https://doi.org/10.1016/j.ijantimicag.2020.105949

60. Cortegiani A, Ingoglia G, Ippolito M, Giarratano A, Einav S (2020) A systematic review on the efficacy and safety of chloroquine for the treatment of COVID-19. J Crit Care 57:279-283. https://doi.org/10.1016/j.jcrc.2020.03.005
61. Deming D, Sheahan T, Heise M, Yount B, Davis N, Sims A, Suthar M, Harkema J, Whitmore A, Pickles R, West A, Donaldson E, Curtis K, Johnston R, Baric R (2006) Vaccine efficacy in senescent mice challenged with recombinant SARS-CoV bearing epidemic and zoonotic spike variants. PLoS Med 3(12):e525. https://doi.org/10.1371/journal.pmed.0030525

62. Yasui F, Kai C, Kitabatake M, Inoue S, Yoneda M, Yokochi S, Kase R, Sekiguchi S, Morita K, Hishima T, Suzuki H, Karamatsu K, Yasutomi Y, Shida H, Kidokoro M, Mizuno K, Matsushima K, Kohara M (2008) Prior immunization with severe acute respiratory syndrome (SARS)-associated coronavirus (SARS-CoV) nucleocapsid protein causes severe pneumonia in mice infected with SARS-CoV. J Immunol 181(9):6337-6348. https://doi.org/ 10.4049/jimmunol.181.9.6337

63. Bolles M, Deming D, Long K, Agnihothram S, Whitmore A, Ferris M, Funkhouser W, Gralinski L, Totura A, Heise M, Baric RS (2011) A double-inactivated severe acute respiratory syndrome coronavirus vaccine provides incomplete protection in mice and induces increased eosinophilic proinflammatory pulmonary response upon challenge. J Virol 85(23):12201-12215. https://doi. org/10.1128/JVI.06048-11

64. Lurie N, Saville M, Hatchett R, Halton J (2020) Developing COVID-19 vaccines at pandemic speed. N Engl J Med 382(21):1969-1973. https://doi.org/10.1056/NEJMp2005630

65. Thevarajan I, Nguyen THO, Koutsakos M, Druce J, Caly L, van de Sandt CE, Jia X, Nicholson S, Catton M, Cowie B, Tong SYC, Lewin SR, Kedzierska K (2020) Breadth of concomitant immune responses prior to patient recovery: a case report of non-severe COVID-19. Nat Med 26(4):453-455. https://doi.org/10.1038/ s41591-020-0819-2

66. Wu HS, Hsieh YC, Su IJ, Lin TH, Chiu SC, Hsu YF, Lin JH, Wang MC, Chen JY, Hsiao PW, Chang GD, Wang AH, Ting HW, Chou CM, Huang CJ (2004) Early detection of antibodies against various structural proteins of the SARS-associated coronavirus in SARS patients. J Biomed Sci 11(1):117-126. https://doi.org/10. 1007/BF02256554

67. Bloch EM, Shoham S, Casadevall A, Sachais BS, Shaz B, Winters JL, van Buskirk C, Grossman BJ, Joyner M, Henderson JP, Pekosz A, Lau B, Wesolowski A, Katz L, Shan H, Auwaerter PG, Thomas D, Sullivan DJ, Paneth N, Gehrie E, Spitalnik S, Hod EA, Pollack L, Nicholson WT, Pirofski L, Bailey JA, Tobian AAR (2020) Deployment of convalescent plasma for the prevention and treatment of COVID-19. J Clin Invetig 130:2757-2765. https://doi.org/ 10.1172/JCI138745

68. Brown BL, McCullough J (2020) Treatment for emerging viruses: convalescent plasma and COVID-19. Transfus Apher Sci 59(3):102790. https://doi.org/10.1016/j.transci.2020.102790

69. Casadevall A, Pirofski LA (2020) The convalescent sera option for containing COVID-19. J Clin Invest 130(4):1545-1548. https:// doi.org/10.1172/JCI138003

70. Cheng Y, Wong R, Soo YO, Wong WS, Lee CK, Ng MH, Chan P, Wong KC, Leung CB, Cheng G (2005) Use of convalescent plasma therapy in SARS patients in Hong Kong. Eur J Clin Microbiol Infect Dis 24(1):44-46. https://doi.org/10.1007/ s10096-004-1271-9

71. Soo YO, Cheng Y, Wong R, Hui DS, Lee CK, Tsang KK, Ng MH, Chan P, Cheng G, Sung JJ (2004) Retrospective comparison of convalescent plasma with continuing high-dose methylprednisolone treatment in SARS patients. Clin Microbiol Infect 10(7):676-678. https://doi.org/10.1111/j.1469-0691.2004.00956.x

72. Xiao X, Chakraborti S, Dimitrov AS, Gramatikoff K, Dimitrov DS (2003) The SARS-CoV S glycoprotein: expression and functional characterization. Biochem Biophys Res Commun 312(4):1159_ 1164. https://doi.org/10.1016/j.bbrc.2003.11.054

73. Tian X, Li C, Huang A, Xia S, Lu S, Shi Z, Lu L, Jiang S, Yang Z, Wu Y, Ying T (2020) Potent binding of 2019 novel coronavirus 
spike protein by a SARS coronavirus-specific human monoclonal antibody. Emerg Microbes Infect 9(1):382-385. https://doi.org/10. 1080/22221751.2020.1729069

74. Wang C, Li W, Drabek D, Okba NMA, van Haperen R, Osterhaus ADME, van Kuppeveld FJM, Haagmans BL, Grosveld F, Bosch BJ (2020) A human monoclonal antibody blocking SARS-CoV-2 infection. Nat Commun 11(1):2251. https://doi.org/10.1038/ s41467-020-16256-y

75. Tai W, He L, Zhang X, Pu J, Voronin D, Jiang S, Zhou Y, Du L (2020) Characterization of the receptor-binding domain (RBD) of 2019 novel coronavirus: implication for development of RBD protein as a viral attachment inhibitor and vaccine. Cell Mol Immunol 17(6):613-620. https://doi.org/10.1038/s41423-020-0400-4

76. Shu Z, Li P, Yu B, Huang S, Chen Y (2020) The effectiveness of probiotics in prevention and treatment of cancer therapy-induced oral mucositis: a systematic review and meta-analysis. Oral Oncol 102:104559. https://doi.org/10.1016/j.oraloncology.2019.104559

77. Guan W, Lan W, Zhang J, Zhao S, Ou J, Wu X, Yan Y, Wu J, Zhang Q (2020) COVID-19: antiviral agents, antibody development and traditional Chinese medicine. Virol Sin 35(6):685-698. https://doi.org/10.1007/s12250-020-00297-0
78. Johnson RF, Bagci U, Keith L, Tang X, Mollura DJ, Zeitlin L, Qin J, Huzella L, Bartos CJ, Bohorova N, Bohorov O, Goodman C, Kim DH, Paulty MH, Velasco J, Whaley KJ, Johnson JC, Pettitt J, Ork BL, Solomon J, Oberlander N, Zhu Q, Sun J, Holbrook MR, Olinger GG, Baric RS, Hensley LE, Jahrling PB, Marasco WA (2016) 3B11-N, a monoclonal antibody against MERS-CoV, reduces lung pathology in rhesus monkeys following intratracheal inoculation of MERS-CoV Jordan-n3/2012. Virology 490:49-58. https://doi.org/10.1016/j.virol.2016.01.004

79. Berry JD, Hay K, Rini JM, Yu M, Wang L, Plummer FA, Corbett CR, Andonov A (2010) Neutralizing epitopes of the SARS-CoV S-protein cluster independent of repertoire, antigen structure or mAb technology. MAbs 2(1):53-66. https://doi.org/10.4161/ mabs.2.1.10788

Publisher's Note Springer Nature remains neutral with regard to jurisdictional claims in published maps and institutional affiliations. 